\title{
To Boldly Go: Social Clauses in Public Procurement
}

\author{
Catherine Barnard, Trinity College, Cambridge*
}

\begin{abstract}
Public procurement has become exciting for labour lawyers. With the adoption of three new 'revised and modernised' directives on public procurement in 2014, whose express aims include enabling 'procurers to make better use of public procurement to support common societal goals', labour lawyers need to start taking procurement law seriously. At a time when the EU and domestic legislative cupboard in the social field is pretty bare, public procurement may offer a lever to deliver social change. This article will explore some of the potential offered by procurement law to achieve employment law objectives.
\end{abstract}

\section{A. Introduction}

A local authority, let's call it Borsetshire County Council (BCC), has a number of contracts with private providers for facilities management such as cleaning, catering and highways maintenance. It is conscious that staff turnover with these providers is high, pay is low, and staff are provided with little or no training. A number of accidents have occurred in the workplace. BCC is suspicious that the contractors are not providing sufficient staff to do the work properly, nor are those staff receiving their full entitlement to paid leave. BCC also thinks that some of its contractors are not paying the taxes and national insurance contributions that are due. Morale is low among the contract staff and, as a result, the service the local council receives is poor and users are complaining.

BCC therefore decides to revise its procurement processes, introducing a socially responsible procurement policy. ${ }^{1}$ This means that it will require all successful contractors:

(1) to pay the UK living wage to all staff, including the under 25 s, fulfilling any contract with $\mathrm{BCC}$;

\footnotetext{
*My sincere thanks go to Sue Arrowsmith, Chris Bovis, Sjoerd Feenstra, Alberto Sanchez Graells, Amy Ludlow, Josephine Mitchell and Grith Skovgaard Øllyke for helpful comments on earlier drafts of this article, to the two anonymous referees, and to the participants in the seminar 'Procurement and precarity' hosted in Cambridge on 13 May 2015, funded by the Philomathia foundation, and to James Robinson for some particularly helpful insights from practice.

${ }^{1}$ In Scotland, CAs likely to have significant procurement expenditure must have a procurement strategy including a statement of the authority's general policy on, inter alia, the payment of a living wage to persons involved in producing, providing or constructing the subject matter of regulated procurements, promoting compliance by contractors and sub-contractors with the Health and Safety at Work etc. Act 1974 and any provision made under that Act, and the procurement of fairly and ethically traded goods and services ((s.15 Procurement (Reform) Scotland Act 2014)). See also the Statutory Guidance on the Selection of Tenderers on the award of contracts: Addressing Fair Work Practices, including the Living Wage, in Procurement http://www.gov.scot/Resource/0048/00486741.pdf.
} 
(2) to provide evidence of adequate staffing levels for each contract, and the identity of those staff. Further, a certain percentage of the staff must have, as a minimum, NVQ level 3 qualifications or equivalent, and that the remaining staff be offered the opportunity to train to this level or above;

(3) to guarantee that no staff be employed on zero hours contracts (ZHCs);

(4) to ensure that employment laws are being complied with by the contractor and subcontractor in respect of the staff performing the contract, especially in respect of paid annual leave, and that a safe system of work is provided.

Further, BCC plans to exclude any economic operators from the procurement process if BCC discovers they have not paid their taxes or social security contributions. For good measure, and in recognition of the high levels of unemployment among the over 50s in its locality, especially among the ethnic minority community, BCC says it will give preference to contractors owned by ethnic minorities. In addition, it will require that all contractors ensure that at least $10 \%$ of all of their new hires, not just those working on the BCC contract, are over 50 . It also wishes to give preference to contractors who recognise trade unions (it believes that union recognised workplaces have higher standards of health and safety). Finally, it wants guarantees from its suppliers that none of the products they buy have been made using child labour.

Some of BCC's requirements concern the tendering entity itself (eg preference for ethnic minority contractors), and some the production of supplies (eg non-use of child labour). The majority relate to the performance of the contract. Some of these performance conditions apply to all firms operating in the UK (eg compliance with labour law, including the Working Time Regulations 1998). Some exceed what the law requires (eg payment of the UK living wage). The remainder go beyond general compliance with the law and focus instead on so-called 'special' or 'additional' requirements relating to the contract workforce (eg quality of staff, training, hiring of local unemployed, recognised trade union). ${ }^{2}$ The question is whether any or all of these requirements imposed by BCC are compatible with EU - and thus domestic - law.

The answer to this question has become clearer with the adoption of the EU's 2014 legislative package. The package has three elements:

- Directive 2014/23/EU on the award of concession contracts ${ }^{3}$

- Directive 2014/24/EU on public procurement ${ }^{4}$, and

- Directive 2014/25/EU on utilities ${ }^{5}$

The procurement package has the express objective of making better use of public procurement 'in support of common societal goals', including protection of the environment ${ }^{6}$, promoting innovation,

\footnotetext{
${ }^{2}$ These distinctions are based on S. Arrowsmith, 'A taxonomy of horizontal policies in public procurement' in S. Arrowsmith and P. Kunzlik (eds), Social and Environmental Policies in EC Procurement Law: New Directives and New Directions (Cambridge: CUP, 2009).

${ }^{3}$ OJ [2014] L94/1.http://eur-lex.europa.eu/legal-content/EN/TXT/?uri=uriserv:OJ.L .2014.094.01.0001.01.ENG

${ }^{4}$ OJ [2014] L94/65

${ }^{5}$ OJ [2014] L94/243.http://eur-lex.europa.eu/legalcontent/EN/TXT/?uri=uriserv:OJ.L .2014.094.01.0243.01.ENG

${ }^{6}$ Rec. 91 of 2014/24/EU says 'This Directive clarifies how the contracting authorities can contribute to the protection of the environment and the promotion of sustainable development, whilst ensuring that they can obtain the best value for money for their contracts.'
} 
and social inclusion. ${ }^{7}$ As a crude indicator of the magnitude of the change in approach between the 2004 and 2014 procurement directives, there are about 40 references to the word 'social' in the body of Directive 2014/24 (excluding annexes) ${ }^{8}$ as compared with four in the 2004 directive.

We shall focus on the 'General' or 'Public Contracts' Directive 2014/24 (sometimes known as the 'Classic' regime ${ }^{9}$ ). Although due to be implemented by 18 April 2016, ${ }^{10}$ the $\mathrm{UK}^{11}$ brought the Directive into force more than a year early (26 February 2015) by SI 2015/102 Public Contracts Regulations. A large number of the Sl's provisions are copied from the Directive, indicating that the Westminster government got much of what it wished for in negotiations. For this reason, it is thought likely that the UK will continue to apply the Regulations and thus the Directive post-Brexit, at least in the medium term. ${ }^{12}$ Helpfully, the Regulation numbers of SI 2015/102 coincide with their equivalents in the Directive.

In this article I shall refer mainly to the Directive as the source of the rights but with reference to SI 2015/102 where necessary. It will be argued that it is now much easier for contracting authorities $(\mathrm{CAs}),{ }^{13}$ such as $\mathrm{BCC}$, to require economic operators to comply with a range of social clauses. Although such an approach is not without risks, it will be argued that CAs need not only to find the courage to put these requirements in place but also to have a change in mindset. Procurement is no longer just about securing equal treatment of tenderers and transparency in the procurement process but it is also about delivering social (and environmental) objectives.

The article is structured as follows. Section B outlines the changing attitudes towards social clauses in public procurement. Section C considers the general principles which apply in the case of all procurements falling within the General Directive. Section D looks at how the General Directive makes provision for social clauses at the different stages of the procurement process and, taking the $\mathrm{BCC}$ case as an example, examines how the Directive might apply to specific social clauses. Section E concludes.

\footnotetext{
${ }^{7}$ See Rec.s 47 \& 95 of 2014/24/EU and also COM(2011) 15.

${ }^{8}$ These figures exclude the number of times the Economic and Social Committee, social security, and Social services is mentioned.

${ }^{9}$ Member States are permitted to extend the scope of their national regimes beyond that required by EU law so long as it does not conflict with EU law. England and Wales have done so by requiring the Open Procedure to be used and that an advertisement be put on Contracts Finder or Sell2Wales sites, down to very low value thresholds - see Part 8 of SI 2015/102.

${ }^{10}$ OJ [2014] L94/65.http://eur-lex.europa.eu/legalcontent/EN/TXT/?uri=uriserv:OJ.L .2014.094.01.0065.01.ENG

${ }^{\frac{11}{11}}$ The term UK will be used for simplicity. However, most of the Regulations do not extend to Scotland and there are limitations in respect of their application to Northern Ireland and Wales: Regs 1(7) and (8). An action may be ultra vires if it breaches EU law for Scotland (s. 57(2) Scotland Act 1998) and for Wales (s. 80(8) Government of Wales Act 2006). In England, the position is that an action in breach of EU law should be disapplied.

${ }^{12}$ Although of http://researchbriefings.files.parliament.uk/documents/CBP-7213/CBP-7213.pdf, 39.

${ }^{13}$ Art. 2(1) provides that "'contracting authorities"' [CAs] means the state, regional or local authorities, bodies governed by public law or associations formed by one or more such authorities or one or more such bodies governed by public law. Since the term CAs may be unfamiliar it will be used interchangeably with 'state purchasers'.
} 


\section{B. Changing attitudes to social clauses in public procurement}

The power of the public purse to deliver social policy objectives has long been recognised in the UK and abroad. The argument goes that while governments must purchase responsibly and spend taxpayers' money wisely, they also must look after the needs of their population, including those at risk of social exclusion. For this reason, procurement was used in the UK from the 1930s to the early 1990 s as a tool to provide targeted support to depressed regions. ${ }^{14}$ More generally, it has been argued that governments should use their purchasing power ${ }^{15}$ to set an example (what the French describe as l'état exemplaire), ${ }^{16}$ to influence the behaviour of the wider market ${ }^{17}$, and to create a level playing field for competitors based on compliance with the law. Those in favour of the strategic use of public procurement therefore argue that procurement can serve not only a 'purchasing function' (allowing the state to purchase its needs) but also a 'regulatory function' providing a mechanism for enhancing compliance with social standards which more traditional mechanisms, such as individual enforcement, may have failed to ensure. ${ }^{18}$ They might even argue that public procurement can serve a prescriptive function, delivering on social standards beyond the minima laid down by the law.

However, this view is not universally shared. Neo-liberals argue that the objective of procurement law is merely to ensure 'efficiency' ie to mandate outcomes that are as close as possible to those on the private market. For them, procurement should not be used to deliver social policies, certainly beyond what is required by law, because this would add cost and involve state purchasers 'acting other than as a "rational" profit-maximiser'. They also argue that mandating social clauses is 'tantamount to "regulation by contract" which, like other forms of regulation, is thought to be inherently coercive and "inefficient"'. 19

The original EU public procurement directives of the 1970s did not take a clear position on this debate. Their aim was simply to open up the lucrative market in public procurement to potential bidders from across the EU, thereby (1) delivering opportunities for out of state contractors to compete on a level playing field with national providers for the provision of works, supplies and

\footnotetext{
${ }^{14}$ For further detail see S. Arrowsmith, The Law of Public and Utilities Procurement (London, Sweet \& Maxwell, 2005, 2nd ed, vol II), paras 19.2-19.12. Cf Case C-21/88 Du Pont de Nemours Italiana SpA v. Unità sanitaria locale No.2 di Carrara [1990] ECR I-889. However, compare this with Art. 107(3)(a) TFEU which allows state aid to promote the economic development of areas where the standard of living is abnormally low or where there is serious underemployment, and of the regions referred to in Article 349, in view of their structural, economic and social situation.

${ }^{15}$ The Commission says that $17 \%$ of the EU's GDP is spent by public authorities: SEC (2010) 1258.

${ }^{16}$ The Scottish government expressly recognises this: http://www.scottish.parliament.uk/S4 Bills/Procurement\%20Reform/b38s4-introd-pm.pdf, para. 63. ${ }^{17}$ See for example Office of Fair Trading paper OFT742b, September 2004, 'Assessing the impact of public sector procurement on competition'.

${ }^{18}$ As the Commission put it in Buying Social: A Guide to Taking Account of Social Considerations in Public Procurement, SEC (2010) 1258 'By promoting SRPP [Socially Responsible Public Procurement], public authorities can give companies real incentives to develop socially responsible management. By purchasing wisely, public authorities can promote employment opportunities, decent work, social inclusion, accessibility, design for all, ethical trade, and seek to achieve wider compliance with social standards'. See further C. McCrudden, Buying Social Justice: Equality, Government Procurement and Legal Change (Oxford, OUP, 2007). ${ }^{19}$ These views are summarised and discussed by P. Kunzlik, 'Neo-liberalism and EU Public procurement' (20123) 15 CYELS 283, 324. See also P. Kunzlik, 'The 2014 Public Procurement Package. One Step forward and two back for green and social procurement' in Y. Marique and K. Wauters (eds) EU Directive 2014/24 on Public Procurement - A New Turn for Competition in Public Markets? (Brussels, Larcier, 2016).
} 
services; ${ }^{20}$ and so (2) expose national providers to competition from out of state actors; in order (3) to deliver greater choice and better value for money for state purchasers and, ultimately, the taxpayer. Arrowsmith has described this as the 'internal market' view of the EU procurement law. Given their legal bases (Articles 53, 62 and 114 TFEU), she argues that the 1970s Directives were enacted to ensure that the classic mechanisms of 'prohibiting discrimination, implementing transparency, and removing barriers to access' applied to procurement. ${ }^{21}$

The corollary of this internal market approach was that, given the relatively limited field occupied by the procurement directives and thus EU law, the regulation of 'horizontal' policies, such as social and environmental policies, was a matter for Member States. ${ }^{22}$ This basic division of competence coincided with the original settlement in the founding Treaties ( single market delivered by the EU, social policy by the Member States ${ }^{23}$ ). However, it was never clear whether this division of responsibilities was, in fact, recognised and supported by the EU institutions, ${ }^{24}$ especially the Court of Justice which ruled in the late 80 s/early 90 s that social clauses could breach EU law. ${ }^{25}$ The Court's fear was that by allowing Member States to exercise their discretion to deliver horizontal policies through procurement, they might (and in fact $\mathrm{did}^{26}$ ) operate policies which favoured local producers, thus contravening the general principle of non-discrimination in EU law. ${ }^{27}$

The Court's decisions generally paved the way for an increasingly restrictive approach towards using public procurement as a social tool, especially by the Commission's DG Internal Market, now DG Gro. The Commission increasingly took the neo-liberal line that the objective of the EU Directives was in fact merely to ensure 'efficiency', ${ }^{28}$ An understanding which increasingly fitted the view of a number of Member States, including the UK. ${ }^{29}$

Yet some Member States (particularly in Scandinavia and the Netherlands ${ }^{30}$ ) persisted with social procurement and were eventually aided by the Court which tried to restrain some of the more extreme, restrictive approaches proposed by the Commission. ${ }^{31}$ For example, in Nord-Pas-de-Calais ${ }^{32}$ the Court said the Directive did 'not preclude all possibility for the contracting authorities to use as [an award] criterion a condition linked to the campaign against unemployment provided that that

\footnotetext{
${ }^{20}$ S. Arrowsmith, 'The Purposes of the EU Procurement Directives: Ends, Means and the Implications for National Regulatory Space for Commercial and Horizontal procurement Policies' (2011-12) 14 CYELS 1, 26. ${ }^{21}$ Ibid, 2.

22 Ibid, 46.

${ }^{23}$ C. Barnard, 'EU Employment Law and the European Social Model: The Past, the Present and the Future' (2014) 67 CLP 199.

${ }^{24}$ See further S. Arrowsmith, 'Public Policy as a Tool of Policy and the Impact of Market Liberalisation' (1995) 111 LQR 235.

${ }^{25}$ See eg Case C-360/89 Commission v Italy [1992] ECR I-3401.

${ }^{26}$ See eg Case 45/87 Commission v Ireland (Dundalk Water tender) [1988] ECR 4929; Case C-21/88 Du Pont de Nemours Italiana SpA v. Unità sanitaria locale No.2 di Carrara [1990] ECR I-889 but cf Case 1/87 Beentjes [1988] ECR 4635.. 27

${ }^{28}$ For an example of the Commission's restrictive view, see $\operatorname{COM}(2001) 566$, especially p.15.

${ }^{29}$ For a more recent example, see 'Danish government uses the EU as argument against work clauses', ugebreveta4.dk, 4 Mar. 2015.

${ }^{30}$ For an example of a network of authorities interested in social and environmental innovation in procurement, see the Dutch based http://www.procuraplus.org/.

${ }^{31}$ See eg Case C-513/99 Concordia Bus Finland Oy Ab v Helsingin kaupunki [2002] ECR I-7213, para. 64.

${ }^{32}$ Case C-225/98 Commission v France (Nord Pas de Calais) [2000] ECR I-7445.
} 
condition is consistent with all the fundamental principles of [Union] law, in particular the principle of non-discrimination...'. ${ }^{33}$ This suggested that the Court thought horizontal 'special' or 'additional' requirements clauses were lawful. However, the Commission subsequently offered the narrowest reading of the ruling: ${ }^{34}$ special requirements could be used but only as award criteria (rather than selection criteria) and exclusively in relation to the subject-matter of the contract. This difference of approach generated considerable problems and forced practitioners to take a 'very conservative approach' to avoid projects becoming 'mired in legal uncertainty'. ${ }^{35}$

However, the Nord Pas de Calais case (and Concordia Bus ${ }^{36}$ on environmental policy) did ultimately provide some impetus for change. The 2004 public procurement directives, notably the General Directive $2004 / 18,{ }^{37}$ allowed for the recognition of horizontal policies, especially at performance stage. This view was confirmed by the Court in its seminal decision in Commission $v$ The Netherlands (Fair trade), ${ }^{38}$ concerning the use of the organic and fair trade labels EKO and MAX HAVELAAR. Yet, it was the Lisbon Treaty 2009 that provided the Constitutional trigger for broader change, especially the new Article 3(3) TEU identifying a 'social market economy' as one of the objectives of the Union. ${ }^{39}$ Article 3(3) TEU made clear that social interests were no longer secondary to the economic aims of the EU, ${ }^{40}$ a theme picked up by the Commission in its 2010 guide to Buying Social. ${ }^{41}$ The same year saw the adoption of the EU2020 strategy, where public procurement was identified as 'one of the market-based instruments' to achieve the EU2020 strategy of 'smart, sustainable and inclusive growth' 'while ensuring the most efficient use of public funds'. ${ }^{42}$

In the UK, despite the continued existence of s.17 of the Local Government Act (LGA) 1988 which prohibits local authorities from taking non-commercial factors ${ }^{43}$ into account in procurement, various state purchasers especially in Scotland ${ }^{44}$ and Northern Ireland, ${ }^{45}$ have adopted increasingly 'social' approaches to procurement, especially using contractual clauses promoting equality as part

\footnotetext{
${ }^{33}$ Para. 50.

${ }^{34}$ General Report 2000 - Chapter IX: Community law, para. 1119. It still repeated this caveat in its 2010 Buying Social Guide, above n. 17, p. 40.

${ }^{35}$ B. Doherty, 'The United Kingdom', Public Procurement Law: Limitations, Opportunities and Paradoxes, The XXVI FIDE Congress in Copenhagen, 2014, 792 discussing twenty procurement contracts in Northern Ireland which had a special condition requiring the employment of the unemployed, an equality issue under 5.75 Northern Ireland Act 1998 since Catholics in Northern Ireland were twice as likely to be unemployed as Protestants

${ }^{36}$ See eg Case C-513/99 Concordia Bus Finland Oy Ab v Helsingin kaupunki [2002] ECR I-7213.

${ }^{37}$ OJ [2004] L134/114.

${ }^{38}$ Case C-368/10 EU:C:2012:284, para. 76.

${ }^{39}$ For a discussion of this term, see C. Joerges and F. Rödl, “'Social Market Economy” as Europe's Social Model?' EUI Working Paper Law No. 2004/8.

${ }^{40}$ See AG Cruz Villalón in Case C-515/08 Santos Palhota ECLI:EU:C:2010:245, para. 51. See also the horizontal clauses, Art. 8 TFEU on equality between men and women, the new Art. 9 TFEU on the promotion of 'a high level of employment ... and a high level of education, training and protection of human health', and Art. 10 TFEU on non-discrimination.

${ }^{41}$ See eg Commission, above n. 34.

${ }^{42}$ Rec. 2 of the General Directive.

${ }^{43}$ Such as the terms and conditions of employment by contractors of their workers or the composition of, the arrangements for the promotion, transfer or training of or the other opportunities afforded to, their workforces - see s.17(5)(a). This legislation does not apply to Northern Ireland.

${ }^{44}$ See above n. 1. See also http://www.scotland.gov.uk/Topics/Government/Procurement/policy/corporateresponsibility/CSR/SSPAP/ComBen.

${ }^{45}$ Doherty, above n. 35, 789-793.
} 
of the public sector equality duty. ${ }^{46}$ The Local Government Act 1999 did introduce the duty of best value for local authorities which includes overall value, including economic, environmental and social value, when reviewing service provision.

Finally, the Public Services (Social Value) Act 2012 more overtly supports an increasingly 'social' view of procurement (and so necessarily qualifies s.17 LGA $1988^{47}$ ). It places an obligation on all public authorities to consider, at the pre-procurement stage, how a service (not works or goods) being procured might improve, inter alia, the social well-being of an area and how the authority can carry out the procurement process to achieve that improvement. ${ }^{48}$

Given this background, how has the promotion of social matters manifested itself in concrete terms in the General Directive 2014/24 and thus the Regulations? The winds of change can be seen most obviously in the general principles of procurement.

\section{General principles}

Article 18(1) contains the classic principles of procurement: 'Contracting authorities shall treat economic operators equally and without discrimination and shall act in a transparent and proportionate manner.' Then, crucially for labour lawyers, comes the new Article 18(2):

Member States shall take appropriate measures to ensure that in the performance of public contracts economic operators comply with applicable obligations in the fields of environmental, social and labour law established by Union law, national law, collective agreements or by the international environmental, social and labour law provisions listed in Annex X.

The international social conventions identified in Annex X reflect the ILO's eight core labour standards: ${ }^{49}$ ILO Conventions 87 (Freedom of Association and the Protection of the Right to Organise), 98 (the Right to Organise and Collective Bargaining), 29 (Forced Labour), 105 (the Abolition of Forced Labour), 138 (Minimum Age), 111 (Discrimination (Employment and Occupation)), 100 (Equal Remuneration); and 182 (Worst Forms of Child Labour).

\footnotetext{
${ }^{46} \mathrm{http} / / /$ www.equalityhumanrights.com/publication/buying-better-outcomes-mainstreaming-equalityconsiderations-procurement-guide-public-authorities.

${ }^{47}$ S.17(11) LGA 1988. S.17 has also been amended to accommodate the public sector equality duty (see s.17(10) LGA 1988).

${ }^{48}$ The Procurement Reform (Scotland) Act 2014 contains a similar sustainable procurement duty in s.9 which provides that before carrying out a regulated procurement, the CA must consider how in conducting the procurement process it can 'improve the economic, social, and environmental wellbeing of the authority's area', references to the wellbeing of the authority's area include, in particular, reducing inequality in the area. For large contracts ( $€ 4 \mathrm{~m}$ plus), there is a community benefit requirement relating to training and recruitment, or the availability of subcontracting opportunities, or relating to the improvement of the economic, social or environmental wellbeing of the authority's area in a way additional to the main purpose of the contract (s.24). ${ }^{49} \mathrm{http}$ ://www.ilo.org/wcmsp5/groups/public/---asia/---ro-bangkok/---iloislamabad/documents/policy/wcms 143046.pdf. The Annex X list can be amended by delegated act adopted under Article 56(4). Noticeable by its absence is ILO Convention No. 94 on labour clauses (public contracts). For discussion of Convention No.94, see ILO, 'Labour Clauses in Public Contracts: Integrating the Social Dimension into procurement policies and practices', 97th session, 2008. See also E. Van den Abeele, 'The Reform of the New EU public procurement rules open door for better social and environmental protection', ETUI working paper, 16 Nov. 2014.
} 
The 'labour law' clause in Article 18(2) is an important innovation. ${ }^{50}$ It is drafted in mandatory terms ('Member States shall take appropriate measures') and in general terms ('social and labour law established by Union law, national law, collective agreements'). And the reference to collective agreements is general: unlike the limitations laid down in the Posted Workers Directive 96/71, ${ }^{51}$ there is no condition that the collective agreement be universally applicable nor is there any requirement, that, for example, pay be set only at the minimum rate. The only limitation is that Article 18(2) applies 'in the performance of public contracts'. However, Recital 40 goes further ${ }^{52}$ and, reflecting the language of Commission v Germany (occupational pensions), ${ }^{53}$ suggests that account should be taken of social (and environmental) provisions throughout the performance of the procurement process.

The UK has decided not to implement Article 18(2) as such, although Article 18(2) is referred to in various provisions of its Regulations. ${ }^{54}$ Rather, it will adopt guidance, due to be published shortly, ${ }^{55}$ making it policy to mirror these obligations in contract clauses backed up by a standard contract condition. ${ }^{56}$ We shall return to Article $18(2)$ below.

\section{The Stages in a Procurement Process and the use of social provisions}

There are multiple stages in a procurement process: preparation, technical specification, publishing the OJEU notice, bidder selection, bidder 'down-selection', award, standstill and debriefing, contract completion and then contract performance. We shall focus on the stages at which there is potential to take social matters into account.

\section{Preparation stage}

The Directives do not, as such, apply to the preparation stage. Fundamentally, the decisions of whether to purchase, what to purchase and which state body will do the purchasing are left to Member States. However, the definition of what is being purchased is crucial in deciding what the contract is for. This is especially important when determining whether a particular condition can be justified as 'linked to the subject matter of the contract' (see below). ${ }^{57}$

The 2014 General Directive encourages state purchasers to undertake preliminary market consultations with a view to preparing the procurement and informing economic operators of their

\footnotetext{
${ }^{50}$ The ILO Conventions had been referred to in Rec. 33 to the 2004 Directive.

${ }^{51}$ OJ [1997] L18/1.

52 The Court certainly takes the recitals into account to 'elucidate' the substantive provisions of the Directive: Case C-368/10 Fair Trade EU:C:2012:284, para. 85.

${ }^{53}$ Case C-271/08 [2010] ECR I-7091.

${ }^{54}$ The UK has ratified all eight core labour Conventions: http://www.ilo.org/dyn/normlex/en/f?p=NORMLEXPUB:11200:0::NO::P11200_COUNTRY_ID:102651.

${ }^{55}$ Email on file with the author.

${ }^{56}$ Cabinet Office, Consultation Document: UK Transposition of new EU Procurement Directives, 19 Sept 2014, 22.

57 In training procurers in sustainable procurement, the Scottish government suggests that people consider risk and opportunities arising for commodity groups and define the subject matter of the contract as a means of clear linkage to social and environmental aims. Scotland has a lot of (non-procurement) policy to support this approach, principally the National Performance Framework and National Outcomes (http://www.scotland.gov.uk/About/Performance/scotPerforms/outcome).
} 
plan and requirements. ${ }^{58}$ This may include prior involvement of candidates or tenderers so long as it is done in a fair way so that those consulted do not get more useful information than other eventual bidders. ${ }^{59}$ In the case of services, these consultations create the opportunity for contracting authorities (CAs) in England and Wales to consider social value under the 2012 Act, and how it might be factored into the tender.

The preparation stage also allows CAs to consider whether the contract benefits from a 'set-aside' ie it can be reserved for a particular group of suppliers. Building on the 2004 Directive, Article 20(1) provides that Member States may reserve participation in procurement to a) sheltered workshops; b) economic operators whose main aim is the social and professional integration of disabled or disadvantaged persons; or c) sheltered employment programmes, provided that in all three cases at least $30 \%$ (down from 'most' in the 2004) of the employees are disabled or disadvantaged workers. This new reference to 'disadvantaged workers' includes the 'unemployed, members of disadvantaged minorities or otherwise socially marginalised groups ${ }^{60}$ such as the Roma and older workers, groups which have long been identified in the EU's employment strategy as needing special support. ${ }^{61}$

The set-aside envisaged by the Directive is only partial: procurement rules still apply to such contracts but only organisations meeting the Article 20 criteria can bid. ${ }^{62}$ This does, however, mean that disadvantaged groups from other Member States may win the contract.

\section{Technical specification stage}

The technical specification stage requires contracting authorities to identify what they want to procure, namely 'the characteristics required of a works, service or supply' (Article 42(1)) and to set out the minimum specifications. ${ }^{63}$ Even prior to the 2014 Directive, the Commission had said that it was possible at this stage to specify in a contract for works, measures to avoid accidents at work and specific conditions for storage of dangerous products in order to safeguard the health and safety of workers ${ }^{64}$ This is of relevance to BCC in respect of, for example, any contracts it wishes to award in respect of highway maintenance, catering in schools or cleaning. As with the 2004 Directive, the 2014 Directive makes provision for CAs to insist upon accessibility criteria for people with disabilities, but the obligation now is more robust. ${ }^{65}$

\footnotetext{
${ }^{58}$ Article 40. It was implicitly permitted previously (Case C-21/03 Fabricom SA v. Belgian State [2005] ECR I1559 ) and utilised by some CAs without problems but the lack of legal uncertainty around it caused many CAs to shy away from this helpful step.

${ }^{59}$ Article 41 which refers to avoiding distortions of competition and violations of principles of non-

discrimination and transparency.

${ }^{60}$ See also Rec. 36.

${ }^{61}$ See eg Guideline 7 of the Guidelines for the Employment Policies of the Member States Council Dec. 2010/707 (OJ [2010] L308/46) which have been repeated annually since then. See also http://ec.europa.eu/justice/discrimination/roma/index_en.htm.

${ }^{62}$ Article 20(2) adds: 'The call for competition shall make reference to this Article.'

${ }^{63}$ Article 45 allows CAs to authorise or require tenderers to submit variants. While the variants must also be linked to the subject matter of the contract, this possibility might create space for innovative use of social policies.

${ }^{64}$ See above n. 41, 29.

${ }^{65}$ Art. 42(1), fourth and fifth subparas.
} 
Most striking and important is the recognition of the possibility for CAs to specify PMPs (process or methods of production), namely criteria concerning the production of supplies but which have no effect on the characteristics of the product, supplies which are then used by the winning bidder in the performance of the contract. ${ }^{66}$

Article 42(1) provides that the characteristics of the works, services or supply may

refer to the specific process or method of production or provision of the requested works, supplies or services or to a specific process for another stage of its life cycle even where such factors do not form part of their material substance, provided that they are linked to the subject-matter of the contract and proportionate to its value and its objective' ${ }^{67}$

So, for example, the CA might specify in a contract to procure coffee that the coffee is purchased at a fair price and under fair conditions from small scale producers in developing countries. ${ }^{68}$

But the criteria for CAs to be able to specify PMPs are strict. First, PMPs can be used only where they are linked to the subject matter of the contract. This takes us back to the vexed question of what is the subject matter of the contract (which is for BCC to define). In the case of a CA wishing to buy coffee from fair trade sources it would be sensible to define the subject matter of the contract as the purchase of 'fair trade coffee' ${ }^{69}$ But what about BCC's requirement that its supplies - say 10,000 uniforms for staff - must not be produced using child labour? What is the subject matter of the contract? If it is narrowly construed as 'uniforms', then it is hard to argue that the non-use of child labour makes any difference to what is being purchased (uniforms) and so the requirement that (not using child labour) is not linked to the subject matter of the contract and so cannot be applied. One way round this would be to say that too narrow a reading would deprive Article 42(1) of its effect, ${ }^{70}$ especially since Article 42(1) expressly recognises that the PMPs do not need to form part of the material substance of the contract. Another would be to argue that given the reputational damage resulting from buying uniforms made by child labour, then 'not using child labour' is part of the subject matter of the contract.

\footnotetext{
${ }^{66}$ PMPs that did affect the characteristics of the product (eg running costs, re-use, recycling or disposal costs) had been allowed prior to the 2014 Dir. Case C-368/10 Fair Trade EU:C:2012:284 (decided after the publication of the Commission's proposal for the 2014 Dir. but before their adoption had accepted the legality of PMPs which had no effect on the characteristics of the product). See further P. Kunzlik, 'From Suspect Practice to Market-based Instrument: Policy Alignment and the Evolution of EU Law's Approach to 'Green' Public Procurement (2013) 22 Public Procurement Law Review 97.

${ }^{67}$ Article 42(1), emphasis added.

${ }^{68}$ These were the facts in Case C-368/10 Fair Trade EU:C:2012:284, paras. 73-6 but were not allowed then as technical specifications, only as performance conditions.

${ }^{69}$ Since this requirement goes directly to bidder price for this tender (because it is an obligation in this tender to avoid cloth and manufacturing facilities which are cheaper because they avoid the PMP requirement). As the PMP requirement can be demonstrated to go to price, it should be seen as part of the subject matter of the contract.

${ }^{70} \mathrm{~A}$ further possible route would be to draw an interpretative steer from the EU's Charter of Fundamental Rights, in particular Article 24 (the rights of the child) and Article 32 (prohibition of child labour). This might persuade the Court to construe 'uniforms not using child labour' as the subject matter of the contract. See, by analogy, Case C-244/06 Dynamic Medien Vertriebs GmbH v Avides Media AG [2008] ECR I-505. The fact that potential suppliers must be excluded from bidding if they have been convicted of using child labour might support this reading of the subject matter of the contract. See also Art. 57(1)(f) considered below.
} 
A final route is to adopt a broader reading of the phrase 'linked to the subject matter of the contract', namely that BCC can specify 'not using child labour' as a requirement but that this requirement applies only to the supply of uniforms to it, BCC (ie linked to the subject matter of BCC's contract); it cannot insist that all clothing provided by the successful supplier to all of its purchasers not be made using child labour.

Having considered the first limitation on the use of PMPs (linked to the subject matter of the contract), we turn now to consider the second limitation on the use of PMP specifications: the PMPs must be proportionate to the contract's value and its objectives. It can be difficult to put every PMP in monetary terms. The difference in price in using 'Fair Trade' and un-accredited coffee can be identified and considered because both are available options within the marketplace. It is much harder to monetarise the prevention of child labour if, as is hoped, child labour is not available in the market. A strict approach to the proportionality principle could therefore result in the deliberate change to Article 42 being undermined. This cannot have been the intention of the legislation.

There are other limitations which apply to all technical specifications including but not limited to PMPs. Specifications must afford equal access to the procurement procedure and must not have the effect of creating unjustified obstacles to the opening up of procurement to competition. These are, effectively, a requirement to state the specifications in the most neutral way which can be achieved. This is particularly important in IT projects where, for example, if the language or operating system on a server are specified unnecessarily, a significant part of the market may be excluded.

Article 43 allows the CA to require a specific label as means of proof ${ }^{71}$ that the works, services or supplies correspond to the required social characteristics. ${ }^{72}$ So labels could relate to workforce issues (eg fair trade labels). The label requirements must, however, satisfy a number of criteria, including, again, that they be linked to the subject-matter of the contract, that the requirements are based on transparent and non-discriminatory criteria, that the label is awarded by a body independent of the supplier applying for the label and that equivalents are accepted.

\section{Supplier selection stage}

\subsection{Introduction}

Having determined what it wants to buy and specified the detail of what it is purchasing, the CA then needs to consider the characteristics of the potential supplier. This stage is essentially backwardlooking: what has the supplier done in the past as an indicator of its capability and its suitability to fulfil the current contract? This is assessed by suppliers completing the Pre Qualification Questionnaire (PQQ). The Directive deals with two situations:

(1) verification of the supplier's capacity to fulfil the contract (ie capability criteria: 3.2 ); and

(2) (bad) things which the supplier has done which may or must lead to the exclusion of the contractor (ie suitability criteria: 3.3 ).

A bidder which fails selection will be excluded. Even if a bidder does not fail selection it may still be 'down-selected' to make the award process more manageable for the CA (3.4).

\footnotetext{
${ }^{71}$ This confirms Case C-368/10 Fair Trade EU:C:2012:284, para. 64.

${ }^{72}$ See also Rec. 75.
} 
There have been examples where mandatory elements at the selection stage have been used covertly to give preference to a local provider. As a result, the selection stage is tightly controlled. The lack of flexibility is not necessarily a problem for BCC as selection is only about excluding bidders who cannot perform the contract. Subsequent stages give more flexibility to BCC to reflect its values so that, even when a bidder is not excluded on selection, their bid will score in a way which reflects BCC's concerns about social factors (see below).

\subsection{Selection Criteria}

Article 58 concerns 'selection' criteria:

- suitability to pursue the professional activity;

- economic and financial standing;

- technical and professional ability.

These criteria concern the supplier's ability to deliver the specific contract, namely minimum levels of capacity to be met by suppliers in order to qualify to participate in the procurement competition. Account cannot be taken here of the supplier's general policies on, for example, equal opportunities. This view is supported by Fair Trade ${ }^{73}$ where the Court said that (what is now) Article 58 'exhaustively lists the factors on the basis of which the contracting authority may evaluate and assess the technical and professional abilities of tenderers' (emphasis added). On the facts, the CA used the requirement of respect for the criteria of sustainable purchasing and socially responsible business as a selection criteria. This was unlawful because it was not connected with any of the Article 58 criteria.

Article 58 of Directive 2014/24 has not created very much more space for incorporating social factors into the selection criteria than existed under the 2004 Directive. However, it does provide that, with regard to technical and professional ability, CAs may impose requirements ensuring that economic operators possess the necessary human and technical resources and experience to perform the contract to an appropriate quality standard. Thus, Article 58(4) would suggest that BCC can impose requirements that the economic operator needs to have adequate staffing levels and those staff must be adequately qualified for the job.

In its Procurement (Reform) Act 2014 the Scottish government goes further. S.29 expressly gives powers to Scottish Ministers to publish guidance (to which CAs must have regard) about the selection of economic operators and the award of contracts in relation to a regulated procurement which may cover matters relating to:

(i) the recruitment, remuneration (including payment of a living wage) and other terms of engagement of persons involved in producing, providing or constructing the subject matter of the regulated procurement, and

\footnotetext{
${ }^{73}$ Case C-368/10 Commission v Netherlands EU:C:2012:284, para. 105-8. See also Case C-31/87 Beentjes [1988] ECR 4635, para. 28 (lowest tender rejected because the tenderer could not comply with the requirements that the contract workforce be comprised of $70 \%$ long-term unemployed; not lawful ground for exclusion because not listed in Directive).
} 
(ii) employee representation including trade union recognition, ${ }^{74}$

Subsection (i) allows Ministers 'to address current known workforce related issues, for example, inappropriate use of zero hours contract, whilst retaining the flexibility to respond quickly to future issues' ${ }^{75}$ Such provisions may make the job of socially progressive councils, like BCC, easier in Scotland than in England and Wales.

\subsection{Exclusions}

While Article 58 concerns eligibility criteria set by CAs for the individual procurement competition, Article 57 details the grounds on which an economic operator can or must be excluded even where they satisfy the eligibility criteria. The exclusions serve a disciplinary and reputational function. They are disciplinary in that they contain a significant sanction for misconduct by potential bidders. ${ }^{76}$ They also serve to protect the reputation of the $C A$, ensuring that the $C A$ is not associated with illegal conduct. $^{77}$

The Directive allows for exclusions in two cases. First, there are the mandatory exclusions. ${ }^{78}$ These now include, in Article 57(1)(f), the situation where the contracting authority has established that that the economic operator has been the subject of a 'conviction by final judgment' for 'child labour and other forms of trafficking in human beings as defined in Article 2 of Directive 2011/36/EU of the European Parliament and of the Council'.

Of particular relevance to $\mathrm{BCC}$ is that the CA must also now exclude a contractor where it is aware that 'the economic operator is in breach of its obligations relating to the payment of taxes or social security contributions and where this has been established by a judicial or administrative decision having final and binding effect in accordance with the legal provisions of the country in which it is established or with those of the Member State of the contracting authority'. ${ }^{79}$ However, the Directive allows Member States to provide a derogation from this mandatory exclusion 'where an exclusion would be clearly disproportionate', for example where only minor amounts of taxes or social security contributions are unpaid. ${ }^{80}$

\footnotetext{
${ }^{74}$ See also the Scottish government's PQQ: http://www.gov.scot/Topics/Government/Procurement/buyerinformation/standardformsanddocs/sPQQ0214.

${ }^{75}$ http://www.scottish.parliament.uk/S4 Bills/Procurement\%20Reform/b38s4-introd-pm.pdf, para. 90.

${ }^{76}$ See eg Rec. 101.

${ }^{77}$ See eg http://www.scottish.parliament.uk/S4 Bills/Procurement\%20Reform/b38s4-introd-pm.pdf, para. 86.

${ }^{78}$ These exclusions can occur at any stage during the procedure (Art. 57(5), first para).

${ }^{79}$ Art. 57(2) and Rec. 100 (emphasis added). There is also a discretionary exclusion (see below) where the CA can demonstrate that the economic operator has not paid its taxes or social security contributions but where no legally binding decision has been taken (Art. 57(2), second para). The mandatory and discretionary exclusions cease to apply (Art. 57(2), third para) when the economic operator has paid the money due, together with any interest or fines, or entered a binding arrangement to do so. Art. 57 therefore concerns 'ongoing default, not past violations' (S. Arrowsmith, The Law of Public and Utilities Procurement: Regulation in the EU and UK, vol. 1, (London, Sweet and Maxwell, 2014, $3^{\text {rd }}$ ed), 12-93, although she suggests that nonpayment of taxes and social security contributions may still constitute grave misconduct (12-94) under Art. 57(4)(c). For an example of where such an exclusion might apply, see http://www.theguardian.com/society/2014/dec/07/saatchi-cleaners-fight-unpaid-wages-low-pay. ${ }^{80}$ Article 57(3), building on Case C-358/12 Consorzio Stabile Libor Lavori Pubblici v. Comune di Milano EU:C:2014:2063. See also Rec. 101, second para., on the importance of the proportionality principle. The UK has given CAs the choice to do this: Reg 56(7).
} 
Secondly, there are the discretionary grounds for exclusion ${ }^{81}$ which generally concern the suppliers' 'professional honesty, solvency and reliability'. ${ }^{82}$ Article 57(4)(a), which is new, allows the CA to exclude a potential bidder where it can demonstrate by any 'appropriate means' (thus not necessarily only tribunal proceedings) a violation of applicable obligations referred to in the labour law clause in Article 18(2). Despite not implementing Article 18(2) itself, the UK has given effect to Article $57(4)(a) .{ }^{83}$ This is of relevance to BCC in its attempts to combat non-compliance with the Working Time Regulations 1998 and the National Minimum Wage Act 1998: it has the discretion to exclude bidders whom BCC can sensibly demonstrate have not complied with the law. ${ }^{84}$

Article 57(4)(a) is a robust provision but its very robustness creates a problem. It may mean that an employer, who has lost an employment tribunal claim for, say, sex or race discrimination or unfair dismissal, or even potentially against whom the Gangmasters Licensing Authority (GLA) has received a complaint, could be excluded from contracting. While this might create a significant incentive for compliance with labour law generally (the requirement not to breach labour laws is not confined to those involved in fulfilling the contracts), any CA adopting such an approach may be at a real risk of being challenged on whether its decision to remove is disproportionate and/or breaches the general principles of procurement laid down in Article 18(1). ${ }^{85}$

So far, however, the indications are that the Courts may back exclusion. Exclusion of a bidder has been approved by the courts where the bidder refused to sign a document confirming it had no links with organised crime ${ }^{86}$; where the bidder had been fined for being in a competition cartel ${ }^{87}$; where a bidder had paid $€ 276$ of monthly social security fees late in relation to a procurement competition for a maintenance contract worth nearly $€ 4.8$ million ${ }^{88}$; and where a bidder failed to promise to pay host workers the legal minimum wage in the country of operation ${ }^{89}$. Not all of these cases relate to exclusion under Article 57(4)(a) but they do appear to indicate that the threshold for the CA to be acting disproportionality may be a difficult one to exceed.

Article 57(4)(c) allows the CA to exclude a potential bidder where the CA can demonstrate by appropriate means that the economic operator is guilty of grave professional misconduct which renders its integrity questionable. ${ }^{90}$ Recital 39 makes clear that non-compliance with collective agreements 'could be considered grave misconduct on the part of the economic operator

\footnotetext{
${ }^{81}$ These exclusions can occur at any stage during the procedure (Art. 57(5), second para).

${ }^{82}$ Case C-226/04 La Cascina Soc. coop. arl and Zilch Srl v Ministero della Difesa and Others [2006] I-1347, para. 21.

${ }^{83}$ Reg. 57(8)(a) which refers to 'a violation of the applicable obligations referred to in regulation 56(2)' which in turn refers to the text of Art. 18(2) and to Annex X of the Public Contracts Directive.

${ }^{84}$ There is also now an express provision on suppliers who have shown 'significant or persistent deficiencies in the performance of a substantive requirement' under a previous contract which might include non-compliance with social clauses (Art. 57(4)(g)).

${ }^{85} \mathrm{Cf}$ Art. 57(4)(c) which talks of 'grave professional misconduct'.

${ }^{86}$ C-425/14 Impresa Edilux ECLI:EU:C:2015:721.

${ }^{87}$ C-470/13 Generali-Providencia Biztosító Zrt v Közbeszerzési Hatóság Közbeszerzési Döntőbizottság ECLI:EU:C:2014:2469.

${ }^{88}$ C-358/12 Consorzio Stabile Libor Lavori Pubblici v. Comune di Milano ECLI:EU:C:2014:2063

${ }^{89}$ C-115/14 RegioPost ECLI:EU:C:2015:760.

${ }^{90}$ This might also cover non-compliance with special conditions in the past: see AG Gulmann's Opinion in Case C-71/92 Commission v Spain [1993] ECR I-5923, para 95.
} 
concerned' ${ }^{91}$ There may be some overlap between Article 57(4)(c) and Article 57(4)(a) but the political push for a stronger and more visible social dimension resulted in Article 57(4)(a) being introduced as a separate provision. ${ }^{92}$

However, while Article 57(4)(a) and (c) create opportunities for BCC, Article 57(6) draws some of the teeth of the provision. It makes explicit provision for the slate to be wiped clean ('self-cleaning') in the case of both mandatory and discretionary exclusions:

Any economic operator that is in one of the situations referred to in paragraphs 1 and 4 may provide evidence to the effect that measures taken by the economic operator are sufficient to demonstrate its reliability despite the existence of a relevant ground for exclusion. If such evidence is considered as sufficient, the economic operator concerned shall not be excluded from the procurement procedure. ${ }^{93}$

Such evidence might include payment in compensation, changes in personnel, appropriate staff reorganisation measures, and the implementation of reporting and control systems. ${ }^{94} \mathrm{It}$ is thought that the need (ability?) to cleanse themselves may have precipitated companies which have blacklisted workers in the building industry to attempt to reach a settlement. ${ }^{95}$

Nonetheless, the threshold for 'self-cleaning' to be judged as 'sufficient' is high. The Directive requires that the bidder must prove a) that it has paid or undertaken to pay compensation in respect of any damage caused by the criminal offence or misconduct; b) clarified the facts and circumstances in a comprehensive manner by actively collaborating with the investigating authorities; and c) taken concrete technical, organisational and personnel measures that are appropriate to prevent further criminal offences or misconduct. ${ }^{96}$ The measures taken by the economic operators must be evaluated taking into account the gravity and particular circumstances. Reasons must be given for any decision by the CA that the evidence is not sufficient.

In the absence of self-cleaning, the maximum period of exclusion is 5 years from judgement in the case of mandatory exclusions, three years from the event in the case of discretionary exclusions and the Directive is clear that 'self-cleaning' is not a way of reducing any exclusion imposed by a court (as opposed to the CA excluding a bidder). ${ }^{97}$

\subsection{Reduction in the number of bidders}

Even if a bidder has made it through the PQQ, it may still be 'down-selected', as permitted by Article 65 of the General Directive. This is done to make the process more manageable for the CA (and save bidders who have a low chance of winning at the award stage from incurring the costs of preparing an award stage submission in respect of the restricted procedure, the competitive negotiated

\footnotetext{
${ }^{91}$ See also Rec. 101, first para.

${ }^{92}$ S. Arrowsmith, above n. 79, para. 12-101.

${ }^{93}$ The self-cleaning defence will not apply where the Court judgment requires the exclusion of the tenderer from participating in tendering processes.

${ }^{94}$ Rec. 102.

${ }^{95}$ Although cf http://www.gmb.org.uk/newsroom/blacklisting-compensation-not-enough. See also http://www.gov.scot/Topics/Government/Procurement/buyer-information/standardformsanddocs/sPQQ0214 on the Scottish government's approach to blacklisting.

${ }_{96}$ Article $57(6) 2^{\text {nd }}$ and $3^{\text {rd }}$ paragraphs

${ }^{97}$ Art. 57(7).
} 
procedure and the competitive dialogue (CD) procedure). The minimum number of bidders permitted is five for the Restricted procedure and three for the Negotiated and CD procedures. ${ }^{98}$ Down-selection must use the wider-range of award criteria (see below) and not the selection criteria. ${ }^{99}$

\section{Award stage \\ 4.1 MEAT}

The next stage of the procurement process is the 'award' of the contract. This is a misnomer because it means choosing the winning bid, not entering the contract with the eventual winner (known as completion). The concept of MEAT (the 'most economically advantageous tender'), which was used in the previous Directive, is now the overarching criterion to choose a winner. ${ }^{100}$ Article $67(2)$ explains:

The most economically advantageous tender from the point of view of the contracting authority shall be identified on the basis of the price or cost, using a cost-effectiveness approach, such as life-cycle costing in accordance with Article $68,{ }^{101}$ and may include the best price-quality ratio, which shall be assessed on the basis of criteria, including qualitative, environmental and/or social aspects, linked to the subject-matter of the public contract in question. (emphasis added)

Award criteria, unlike PQQ selection criteria, are not bright line 'yes/no' criteria. Bidders are scored against the award criteria which allow bidders to fine-tune their bids between price and quality. The costs/benefit decisions for a bidder ( 'Should I offer the more expensive but better' person/material?) are often a core element of the difference between bids. Accordingly, there is more flexibility for BCC to design criteria to bring out its preference for stronger social standards (e.g. because a bidder will score more quality points per pound expended than other elements so they become a cheaper way to improve the quality, and thus the overall score, despite costing more).

In Fair Trade ${ }^{102}$ the Court had already made clear that CAs were authorised to choose the award criteria based on considerations of a social nature but these could concern only the persons using or receiving the works, supplies or services which were the object of the contract. This is now reflected in part in Article 67(2) which says that the criteria for assessment may comprise, for instance '(a) quality, including ... accessibility, design for all users, social, environmental and innovative characteristics and trading and its conditions'. Article 67(2) also confirms in paragraph (b) that the award criteria cover 'organisation, qualification and experience of staff assigned to performing the contract' but only 'where the quality of the staff assigned can have a significant impact on the level

\footnotetext{
${ }^{98}$ In an Open procedure, no reduction of the number of bidders is permitted. This reflects the fact that, although every Open procedure is able to require that PQQ selection criteria are met, a huge majority of all Open procedure tenders are on the basis of price alone.

${ }^{99}$ Article 66

100 Article 67(1).

${ }^{101}$ See also Rec. 96 'methodology on social life cycle costing should be examined, taking into account existing methodologies such as the Guidelines for Social Life Cycle Assessment of Products adopted within the framework of the United Nations Environment Programme.'

${ }^{102}$ Case C-368/10 Commission v Netherlands EU:C:2012:284, para. 85.
} 
of performance of the contract ${ }^{103}$. As Recital 94 puts it, this might be the case, for example, in contracts for intellectual services such as consultancy or architectural services ${ }^{104}$. The Recital continues that CAs making use of this possibility should ensure, by appropriate contractual means, that the staff assigned to contract performance effectively fulfil the specified quality standards and that such staff can only be replaced with the consent of the contracting authority which verifies that the replacement staff affords an equivalent level of quality.

The emphasis on quality - which would help BCC in its drive to ensure qualified staff are doing the job - can also be seen in Recital 92 . It says that in the context of the best price-quality ratio, CAs should be encouraged to choose award criteria that allow them to obtain high quality works, supplies and services that are optimally suited to their needs. This may justify a CA insisting on good working conditions. For good measure, Recital 93 says that it is still possible to assess value for money on the basis of other factors than price, such as 'environmental or social aspects, or whether the social integration of disadvantaged persons or vulnerable groups amongst the persons assigned to performing the contract has been furthered.'

Two (controversial) limitations on using social clauses at the award stage have been carried over from the 2004 Directive into Article 67(1): (1) consideration of the MEAT must be seen from the point of view of the CA, and (2) the social criteria must be linked to the subject matter of the contract. These limitations might make it difficult to argue that the successful bidder must have, say, good equal opportunities policies in place since often this may not be economically advantageous from the point of view of the contracting authority and may not be linked to the subject matter of the contract. However, the Court of Justice has taken a broad view of requirement (1) (consideration of MEAT from the perspective of the CA). It has said that CAs may use criteria that are not of a purely economic nature in a monetary sense, including ecological criteria. ${ }^{105}$

Criteria (2) on linkage to the subject matter of the contract has, according to Arrowsmith, 'rule[d] out many criteria relating to secondary policies, such as human rights, social or environmental policies'. ${ }^{106}$ This point was emphasised by the Commission in its Buying Social Communication: ${ }^{107}$ in a works contract for building a school 'the labour conditions of the workers building the school cannot be part of the subject matter of the contract, as they are not linked to the object of the contract, but only to the way in which the procurement contract will be performed'. Later it gave an example of a contract to build a hospital. It says it is not possible to use as an award criterion the creation of new jobs on the local market because such a criterion is not linked to the subject matter of the contract (construction of the hospital) and such a criterion is discriminatory. ${ }^{108}$ The Commission did, however,

\footnotetext{
${ }^{103}$ Emphasis added. This resolves some of the uncertainty generated by Case C-532/06 Lianakis AE $V$ Alexandroupolis [2008] ECR I-251, although of Annex XII, Part II (f) 'the educational and professional qualifications of the service provider or contractor or those of the undertaking's managerial staff, provided that they are not evaluated as an award criterion.

${ }^{104}$ A similar approach has recently been approved under the previous Directive 2004/18/EC for a contract which was 'intellectual in nature' and the criterion was clearly testing the 'professional merit' of bidders towards identifying the most economically advantageous tender: see C-601/13 Ambisig ECLI:EU:C:2015:204 ${ }^{105}$ Case C-513/99 Concordia Bus [2002] ECR I-7213, para. 55, Case C-448/01 EVN \& Wienstrom v. Republik Osterreich [2003] ECR I-1452, paras. 31-34.

${ }^{106}$ Above n.13, para. 7.103. See also Case C-448/01 EVN \& Wienstrom v. Republik Osterreich [2003] ECR I-1452.

${ }^{107}$ Above n. 18, 23.

${ }^{108} \mathrm{Ibid}, 38$.
} 
accept that criteria going beyond the subject-matter of the contract could be applied but only in the single situation of a tie-breaker. ${ }^{109}$

However, these examples and the narrower view of 'linkage' discussed above (in section 2) now need to be read in the light of the new Article 67(3) which contains some key changes:

Award criteria shall be considered to be linked to the subject-matter of the public contract where they relate to the works, supplies or services to be provided under that contract in any respect and at any stage of their life cycle, including factors involved in:

(a) the specific process of production, provision or trading of those works, supplies or services; or

(b) a specific process for another stage of their lifecycle

even where such factors do not form part of their material substance. (emphasis added)

Article 67(3) clarifies two issues. The first concerns the question of linkage itself. Article 67(3) seems to envisage a looser connection ('relates to') between the award criteria and the subject-matter of the public contract. This view is supported by Recital 97 which says that the condition of a link with the subject matter of the contract excludes criteria and conditions relating to general corporate policy. It also says that CAs should not be allowed to require tenderers to have a certain corporate social or environmental responsibility policy in place. ${ }^{110}$ If this is all that is ruled out, then this may well open the way for greater use of social criteria which are related to the subject matter of the contract.

The case law interpreting the 2004 Directive also points in this direction. $\ln E V N^{111}$ the award criteria looked at the total amount of electricity produced from renewable sources which the tenderer was able to supply in general and not the amount which the tenderer would be able to supply specifically to the CA. The Court of Justice said that the award criterion was not linked to the subject matter of the contract. By contrast, in Fair Trade ${ }^{112}$ a different set of facts allowed the Court to rule that because the social award criteria (organic and fair trade) covered only the ingredients to be 'supplied in the framework of that contract, without any bearing on the the general purchasing policy of tenderers' those criteria did relate to products, the supply of which constituted part of the subject-

\footnotetext{
${ }^{109}$ See the Commission's Guide on Buying social, above n. 17, 40. This will prevent the Commission challenging on the point (because it cannot go against its issued guidance during the validity of that guidance) but it will not protect a CA (before national courts or on a reference to the CJEU) if the Commission is judged to be wrong in law.

${ }^{110}$ It would still be legitimate to include a requirement to have a social responsibility policy for the part of the business performing the contract but this may work only if there is some degree of clarity between facilities or people used on the contract and those not used on the contract. It is simply nothing to do with the CA whether the bidder also uses that policy in other situations. However, if the bidder has regular or multiple public sector contracts, it becomes easier for the bidder to implement the policy in respect of all staff than worry whether the correct resources are covered at any particular time. In this way BCC's requirement for the bidder to have a particular policy for that which is relevant to its contract can be a powerful tool if it accidentally encourages the bidder to improve its policies across the board.

${ }^{111}$ Case C-513/99 Concordia Bus [2002] ECR I-7213, para. 59 first established this principle which was more clearly articulated in Case C-448/01 EVN \& Wienstrom v. Republik Osterreich [2003] ECR I-1452. See also Case C-234/03 Contse v Insalud [2005] ECR I-9305, para. 68 and the Commission's Buying Social Communication, above n. 34, 43.

${ }^{112}$ Case C-368/10 Fair Trade EU:C:2012:284, para. 90 (emphasis added).
} 
matter of the contract. ${ }^{113}$ For good measure, the Court added that 'there is no requirement that an award criterion relates to an intrinsic characteristic of a product (ie which forms part of the material substance of the product). Therefore the criterion could refer to the fact that the product concerned was of fair trade origin. ${ }^{114}$ This is now reflected in the language of Article 67(3) ('in any respect and at any stage of their life cycle' (emphasis added).

This broader view of linkage is also the position adopted by the UK government ${ }^{115}$ which notes that 'award criteria must be contract-specific rather than aimed at assessing the corporate policy of the tenderer eg that it would be wrong to award extra points to a supplier that supplied fair trade products to all its suppliers' ${ }^{116}$ It is supported by Kunzlik, too, who says CAs 'may not use their purchasing power to express approval or disapproval of the conduct of particular firms in ways unrelated to the thing being purchased' ${ }^{117}$

So returning to the BCC example, the analysis of Article $67(3)$ would suggest that BCC can use, as an award criteria, special conditions relating to employment of a certain percentage of the unemployed over $50 \mathrm{~s},{ }^{118}$ but that condition can apply only in respect of the BCC contract, not in respect of all of the contractor's new hires in general. ${ }^{119}$ However, award criteria giving preference to firms owned by ethnic minorities, as BCC would like, would not be allowed since the ownership of the firm is not linked to the delivery of the contract itself. More difficult would be a maintenance contract for social housing which provides for additional community benefits as part of the award criteria (eg that the maintenance staff should keep a watchful eye over the elderly residents and help them with oddjobs). ${ }^{120}$ It is not clear whether the additional community benefits would be considered related to the subject matter of the contract (a contract which is for maintenance), although the broad reading or careful specification might allow points for such additional social criteria.

\footnotetext{
${ }^{113}$ Emphasis added.

${ }^{114} \mathrm{Ibid}, 91$.

${ }^{115}$ See also the decision of the French Conseil d'Etat (ECLI:FR:CESSR:2013:364950.20130325, para. 4). In a call for tenders for maintaining roads and green areas, the Isère departmental council required that a certain number of people excluded from the labour market be used to fulfil the contract. The Grenoble administrative court cancelled the call for tender on the basis that 'labour market insertion' efforts were not directly related to the subject-matter of the contract and so could not be used as contract-award criteria by the local authority. However, the Conseil d'Etat ruled that the contract, by its nature, could be implemented by people with a disadvantaged position on the labour market (at least partially), and that therefore the link between the tenderer's performance in social insertion efforts and the subject-matter of the contract existed.

${ }^{116}$ Crown Commercial Service, 'Reform of the EU Procurement rules - public sector, briefing for Procurement Practitioners, 2014, 75. In a similar vein, on performance condition, it says that the conditions cannot relate to actions by the supplier unrelated to that contract (eg employment conditions of the supplier's workforce on contracts for other customers) (p.79).

${ }^{117}$ P. Kunzlik, 'Neo-liberalism and EU Public procurement' (2012-3) 15 CYELS 283, 320.

${ }^{118}$ There is, however, a further issue concerning age discrimination under Dir. 2000/78 OJ [2000] L33/16 but Art. 6(1), specifically (a) on the integration of older workers, does allow direct discrimination to be objectively justified provided it is proportionate. Cf Case C-144/04 Mangold v. Rüdiger Helm [2005] ECR I-9981.

${ }^{119}$ Article 67(3) is less clear as to whether workforce criteria can be used, such as using a certain number of people with disabilities or long-term unemployed or older workers (as BCC wants). However, the reference to 'factors ...not form[ing] part of their [the works, services or supplies'] material substance' would suggest that this is now possible, a view confirmed by the extensive references to social facts in the recitals (see eg Rec. 99). ${ }^{120}$ I am grateful to Sue Arrowsmith for this example. It might be possible to include such a requirement as a technical specification but it would still be subject to the same limitation of needing to be related to the subject matter fo the contract.
} 
Where social award criteria are to be used, this must be made clear upfront. As the Court said in Nord Pas de Calais ${ }^{121}$ 'an award criterion linked to the campaign against unemployment must be expressly mentioned in the contract notice so that contractors may become aware of its existence'. Such an interpretation would fit with the 'internal market' view of the Directives: that they are there to ensure transparency in the tendering process but not to regulate every aspect of what is being procured. Article 67(5) of the Directive also requires the CA to specify in the procurement documents the relative weightings it gives to each of the criteria chosen to determine MEAT, while Article 67(4) makes provision for verification so that, for example, BCC can check whether the tenderer's staff do in fact have NVQ level 3 qualifications.

\subsection{Grounds for not awarding tenders}

There are two legal grounds on which tenders, even if most economically advantageous, may or must not be awarded. First, Article 56(1), second paragraph, provides that CAs may decide not to award a contract to the tenderer submitting the MEAT where they have established that the tender does not comply with the applicable obligations referred to in Article 18(2) (the labour law clause). ${ }^{122}$

Second, in respect of tenders which appear abnormally low, Article 69(1) provides that CAs must require economic operators to explain the price or costs proposed in the tender where the tender appears to be abnormally low in relation to the works, supplies or services. ${ }^{123}$ Article $69(2)$ adds that these explanations may relate to compliance with obligations referred to in Article 18(2) and Article 71 (on subcontracting) (see below). Article 69(3) provides the CA must assess the information provided by consulting the tenderer. It continues that CAs 'shall reject the tender, where they have established that the tender is abnormally low because it does not comply with applicable obligations referred to in Article $18(2)^{\prime}$, ${ }^{124}$ no matter how economically advantageous it might be. ${ }^{125}$ The need to ask the bidder who has submitted the abnormally low bid to explain and for the CA carefully to consider that explanation is an essential for due process. ${ }^{126}$

This is a potentially powerful provision. There is some (so-far anecdotal) evidence that contractors may be winning contracts by not paying holiday pay to their staff. The unpaid holiday pay constitutes the profit margin on the contract. The introduction of tribunal fees in 2013 has meant that the costs associated with going to tribunals may well deter individuals from enforcing their rights to holiday pay. ${ }^{127}$ Such practices, if discovered before the award (possibly following a tip off by a whistleblower?), will now cause the tender to be rejected by a CA such as BCC. Likewise, if BCC discovers that the reason why an economically attractive tender for cleaning is because the tenderer proposes a lower number of workers than is appropriate to the area to be cleaned, the minimum number of workers/hours having been specified in the tender documents, then the tender may be

\footnotetext{
${ }^{121}$ Case C-225/98 Commission v France (Nord Pas de Calais) [2000] ECR I-7445, para. 51.

${ }^{122}$ Article 56(1) forms part of the general principles that apply to Articles 67-69 on award criteria. This has been implemented in the UK Regs including the rules on Article 18(2): Reg. 56(2)

${ }^{123}$ This confirms Case C-599/10 SAG ELV Slovensko a.s. and Others v Úrad pre verejné obstarávanie

EU:C:2012:191, para. 33.

124 See also Rec. 103.

125 The UK has implemented these provisions by reference to Reg. 56(2): Reg. 69(2)(d) and (5).

${ }^{126}$ Reg. 69, SI 2015/102.

${ }^{127}$ See C. Barnard and A. Ludlow, 'Enforcement of Employment Rights by EU-8 Migrant Workers in UK Employment Tribunals'(2016) 45 IL 1-28.
} 
considered abnormally low and may be rejected; it must be rejected if the low relates to noncompliance with Article 18(2). ${ }^{128}$ However, BCC must ensure that it has sensible evidence for its views as to how many staff are needed because BCC's decision to reject the abnormally low tender must be 'reasonable' in a public law sense. Such evidence is, typically, available from the combination of all the other bids. ${ }^{129}$

There is also a helpful procedural provision in Article 69(5): upon request, Member States must make available to other Member States, by means of administrative cooperation, any information at its disposal, such as laws, regulations, universally applicable collective agreements or national technical standards. A pilot project is now underway on the use of the multilingual internal market information system (IMI), an electronic database which allows competent authorities to exchange information transnationally. ${ }^{130}$ This system is already used for exchange of information in connection with the Enforcement Directive on Posted Workers 2014/67. ${ }^{131}$ Brexit raises issues for the UK's continued participation in IMI.

\section{Performance stage}

\subsection{Article 70}

In the past it was the performance stage which offered the greatest scope for including social factors in a contract. This was recognised by the Court in Beentjes ${ }^{132}$ and it was confirmed in Article 26 of the 2004 Directive:

Contracting authorities may lay down special conditions relating to the performance of a contract, provided that these are compatible with [Union] law and are indicated in the contract notice or in the specifications. The conditions governing the performance of a contract may, in particular, concern social ${ }^{133}$ and environmental considerations.

The only two limitations in Article 26 of Directive 2004/18/EC on the use of special conditions relating to contract performance were that the conditions had to be:

- compatible with [Union] law (ie it is no directly nor indirectly discriminatory ${ }^{134}$ ), and

- indicated in the contract notice or in the specifications

Some key changes have been introduced by Directive 2014/24/EU concerning the circumstances in which social criteria can be used at performance stage. Article 70 now provides:

Contracting authorities may lay down special conditions relating to the performance of a contract, provided that they are linked to the subject-matter of the contract within the meaning of Article 67(3) and indicated in the call for competition or in the procurement documents. Those conditions may include economic, innovation-related, environmental, social or employment-related considerations. (emphasis added)

\footnotetext{
${ }^{128}$ Art. 69(3). See further Commission Buying Social communication, above n.18, 41.

${ }^{129}$ See further Case T-495/04 Belfass v. Council [2008] ECR II-00781.

${ }^{130}$ http://ec.europa.eu/internal_market/imi-net/index_en.htm.

${ }^{131}$ OJ [2014] L159/11.

${ }^{132}$ Case 31/87 Beentjes v. State of the Netherlands [1988] ECR 4635.

${ }^{133}$ See further Rec. 33 of Directive 2004/18.

${ }^{134}$ Case C-115/14 RegioPost GmbH EU:C:2015:760, para. 56.
} 
The two limitations are now that:

- the performance conditions must be linked to the subject-matter of the contract, and

- indicated transparently in the call for competition or in the procurement documents.

Thus, the Directive appears to have given with one hand (by broadening the range of special conditions to include social or employment-related considerations) but taken with another (by introducing the requirement that the performance conditions have to be linked to the subject of contract, albeit qualified by the more relaxed, 'related to' test identified in Article 67(3). ${ }^{135}$

The Recitals suggest a generous approach to social considerations. For example, Recital 98 provides that contract performance conditions can favour the implementation of measures for the 'promotion of equality of women and men at work, the increased participation of women in the labour market and the reconciliation of work and private life, ... and to comply in substance with fundamental International Labour Organisation (ILO) Conventions, and to recruit more disadvantaged persons than are required under national legislation' ${ }^{136}$ Recital 99 adds that measures aimed at the protection of the health of the staff involved in the production process, the favouring of social integration of disadvantaged persons or members of vulnerable groups or training in the skills needed can also be the subject of award or performance criteria. This would support BCC with its aim to impose training requirements on successful economic operators. However, the contract will have to be of a fairly long duration if the training requirements include an obligation to provide apprenticeships.

Any such requirements need to be non-discriminatory and proportionate (and otherwise in compliance with EU law although this is no longer expressly stated as it had been in Article 26 of Directive 2004/18). So a requirement that the successful bidder must hire the local unemployed, as BCC may insist, might cause particular problems since it may indirectly discriminate against nondomestic firms. However, as I have argued elsewhere, ${ }^{137}$ indirect discrimination can be justified and the justification may relate to the EU's other policy objectives such as those laid down in the EU2020 strategy on raising employment, especially among older workers. Where the obligation to hire unemployed involves relatively small numbers, such a requirement may be proportionate.

\subsection{Article 18(2) of the Directive}

As we saw above, Article 18(2) of the Directive provides that Member States must take 'appropriate measures' to ensure that in the performance of public contracts economic operators comply with applicable social and labour law. This is a positive development for the enforcement of labour law. It builds on the (rather unknown) principle of procurement that the OJEU Notice and the procurement documentation will govern the performance of the contract procured under them. ${ }^{138}$ It is, however,

\footnotetext{
${ }^{135}$ Para. 102. That said, the Commission maintains (above n. 34, 43) that the linkage requirement already existed under the 2004 Directive.

${ }^{136}$ For an example of the use of equality and diversity in procurement see the Transport for London East London Line project: http://www.rubensteinpublishing.com/default.aspx?id=1111206. See also content.tfl.gov.uk/single-equality-scheme-2012.doc

${ }^{137}$ C. Barnard, 'British Jobs for British Workers': The Lindsey Oil Refinery Dispute and the Future of Local Labour Clauses in an Integrated EU Market' (2009) 38 ILJ 245.

${ }^{138}$ It is clear law that the OJEU scope binds the scope of performance of the contract as well as the scope of the procurement process and any post award but pre-signature negotiations - see Case C-496/99 P Succhi di Frutta [2004] ECR I-3801, paras 115-120.
} 
unfortunate that the Directive did not expressly highlight and address the relationship between the new procurement regime and the Directive on transfers of undertakings 2001/23, ${ }^{139}$ which has caused problems for CAs in the past. ${ }^{140}$ It is also unfortunate that, as with early government attempts to use such labour law clauses, ${ }^{141}$ Article $18(2)$ is drafted in such a general way that it is unlikely to be specifically enforceable (ie it will not satisfy the requirement of direct effect). All of this suggests that ultimately there was a lack of consensus on these key issues.

What does Article 18(2) mean in practice? Where an economic operator from State A or State B has won a contract to provide services/works in Member State $A$ and it will use State $A^{\prime}$ s residents to fulfil the contract, Article 18(2) requires the contractor to comply, as a minimum, with State A's labour laws in respect of State A's workers and those workers migrating to State A under Article 45 TFEU. ${ }^{142}$ This so-called territorial (or equal treatment) approach to labour law has underpinned UK law: all UK labour law rules apply to those working in its territory irrespective of their nationality and, in principle, their length of residence. Where, however, the work is being done in State $B$ to fulfil a service contract in State A, Bundesdruckerei ${ }^{143}$ makes clear that the CA in State A cannot insist that State A's labour law rules apply since this would be contrary to Article 56 TFEU on free movement of services. The General Directive does not appear to affect this outcome. ${ }^{144}$

The position is different where a State B contractor wins a contract in State A and plans to bring posted workers with it to fulfil the contract in State A. The Posted Workers Directive (PWD) 96/71, ${ }^{145}$ as interpreted by the Court of Justice in Laval ${ }^{146}$ and Rüffert, ${ }^{147}$ makes it clear that the host state must require that posted workers benefit from national laws, but only in those areas listed in Articles 3(1)(a)-(g) PWD. This means that a host state CA (such as BCC) cannot insist that, where the contract is being fulfilled by posted workers, they must enjoy all of host state labour law; BCC can insist on compliance only with those host state rules listed in Articles 3(1)(a)-(g) PWD. ${ }^{148}$

\footnotetext{
139 OJ [2001] L82/16.

${ }^{140}$ See further A. Ludlow, 'The Public Procurement rules in action: An empirical exploration of Social Impact and Ideology' (2013-4) 16 CYELS 13.

${ }^{141}$ B. Bercusson Fair Wages Resolutions (London: Mansell Publishers), 1976.

${ }^{142}$ Rec. 37, first para. which talks about Member States and CAs taking the relevant measures to ensure compliance with the social and labour laws 'at the place where the works are executed or the services provided'.

${ }^{143}$ Case C-549/13 Bundesdruckerei GmbH v Stadt Dortmund EU:C:2014:2235.

${ }^{144}$ This view seems to be confirmed by Rec. 37: 'it is of particular importance that Member States and contracting authorities take relevant measures to ensure compliance with obligations in the fields of environmental, social and labour law that apply at the place where the works are executed or the services provided and result from laws, regulations, decrees and decisions, at both national and Union level, as well as from collective agreements, provided that such rules, and their application, comply with Union law' (emphasis added).

145 OJ 1997 L18/1.

${ }^{146}$ Case C- 341/05 Laval EU:C:2007:809.

${ }^{147}$ C-346/06, EU:C:2008:189.

${ }^{148}$ See also Rec. 37 second para. The ETUC has argued that since Laval/Rüffert predated the 2014 procurement package with its greater emphasis on social considerations, the case law should be reconsidered (ETUC, 'New EU Framework on Public procurement: ETUC key points for the transposition of Directive 2014/24/EU', ETUC, 2014, heading 2.3). However, the various references to the PWD in the Recitals suggest that the EU legislature wished to confirm the case law of the Court, not undermine it, especially since the Posted Workers Enforcement Directive 2014/67 (OJ [2014] L 159/11) was being negotiated at the time and the decision had
} 
In respect of pay, Article 3(1)(c) PWD says that the host state can insist that the posted worker be paid the minimum wage, as laid down by law, or by collective agreement which satisfies the conditions laid down in Article 3(8) PWD. ${ }^{149}$ So BCC could insist that a successful bidder which performs the contract using posted workers pay the UK national minimum wage and the national living wage. ${ }^{150}$

What about $\mathrm{BCC}$ 's requirement to pay the UK living wage (not to be confused with the national living wage)? In the UK, the UK Living Wage ( $f 8.25$ outside London, $f 9.40$ in London) is currently not legally binding, ${ }^{151}$ but a significant number of large employers have agreed to pay it. So BCC can probably impose a requirement on tenderers to pay the UK living wage in respect of local workers and migrant workers working in the UK under Article 45 TFEU. It may not be possible to require the UK living wage to be paid in respect of posted workers because Article 3(1)(c) PWD makes clear that host states can require posting companies to pay the minimum wage only, as laid down by law or collective agreement. ${ }^{152}$ This seems to be the intention of Recital 98 of Directive 2014/24:

... the [the award criteria or contract performance conditions] should be applied in accordance with Directive 96/71/EC, as interpreted by the Court of Justice of the European Union and should not be chosen or applied in a way that discriminates directly or indirectly against economic operators from other Member States or from third countries parties to the GPA or to Free Trade Agreements to which the Union is party. Thus, requirements concerning the basic working conditions regulated in Directive 96/71/EC, such as minimum rates of pay, should remain at the level set by national legislation or by collective agreements applied in accordance with Union law in the context of that Directive.

However, as Laval ${ }^{153}$ made clear, Article 3(7) PWD allows posting companies to pay higher rates of pay if they so choose. ${ }^{154}$ While, at first sight, this seems unlikely, they may do so if they think it will (1) strengthen their hand in winning a contract, or (2) to maintain good industrial relations (as in the

been taken not to open up the substance of Dir. 96/71 (cf COM(2016) 128). However, the advent of Dir. $2014 / 24$ may provide some flexibility over specific matters such as a requirement to pay the living wage. 149 Para. 71.

${ }^{150}$ In his 2015 budget, the Chancellor of the Exchequer announced a 'national living wage' - a 50p increase in the statutory minimum pay rate for the over-25s from April 2016, to $f 7.20$ an hour (introduced through amendment to the NMW Regulations 2015), followed by a series of stepped increases expected to take the rate above $\mathrm{f9}$ an hour by 2020. See Case C-115/14 RegioPost GmbH EU:C:2015:760, para. 66, where the Court upheld a minimum wage requirement even where the law applied only to public contracts.

${ }^{151}$ http://www.livingwage.org.uk/.

152 While this might appear to go against the grain of the equal treatment principle established in Article 18(1) of Dir. 2014/24, an approach based on equal treatment was essentially rejected by the Court in Case C-346/06 Rüffert ECLI:EU:C:2008:189 (although more nuanced in Case C-115/14 RegioPost GmbH EU:C:2015:760, albeit RegioPost concerned a minimum wage laid down by (local) law). The circle can be squared by arguing that the position of posted workers and those of national workers is not similar and so the principle of equal treatment is not engaged.

${ }^{153}$ Case C- 341/05 Laval ECLI:EU:C:2007:809.

154 Para. 81. 
case of the Lindsey Oil Refinery ${ }^{155}$ ) or, (3) to professionalise the sector (as experience in the cleaning sector has shown ${ }^{156}$ ). The costs of paying the living wage will, however, be passed on to the CA.

Thus, while voluntary compliance with the living wage would satisfy the PWD, a mandatory obligation would not. Yet, as Koukiadaki shows, ${ }^{157}$ the reality is more complex. Although the UK Cabinet Office has been broadly against the imposition of the living wage, for fear of challenge under EU law, ${ }^{158}$ EU Commissioner McCreevy, in response to a question from Jean Lambert MEP, said 'Living-wage conditions may be included in the contract performance clauses of a public procurement contract provided they are not directly or indirectly discriminatory and are indicated in the contract notice or in the contract documents'. ${ }^{159}$ The response continues 'In addition, [living wage conditions] must be related to the execution of the contract. In order to comply with this last condition, contract performance clauses including living-wage conditions must concern only the employees involved in the execution of the relevant contract, and may not be extended to the other employees of the contractor.' In other words, it is possible to impose a requirement to pay the living wage but the requirement must be linked to the subject matter of the contract (in the broad sense of the phrase).

Such a clear statement on its position on the living wage may suggest that the Commission is unlikely to bring enforcement proceedings against a state where the CA (such as BCC) has imposed a requirement that the supplier pays the living wage. However, the risk remains that an unsuccessful bidder might challenge such a requirement. Yet, such a challenge comes with a cost attached, and a risk that the contractor might sour the relationship with the CA in respect of future tenders. Koukiadaki reports no evidence of such legal challenges, ${ }^{160}$ in part because of the nature of the services involved (eg cleaning, catering) which, when combined with the geographic position of the UK (physically distant from the lower wage economies in Eastern Europe) means that such services are unlikely to be fulfilled by posted, as opposed to migrant, workers.

\subsection{Subcontracting}

Once BCC has decided on the social protections it is building into the contract that it is procuring, it must also think about sub-contracting. If it fails to do so, BCC might find that the main contractor will meet all the standards and policies required but then seeks to avoid them - to win with a cheaper price - through outsourcing the contract to a provider who has lower costs and does not meet the requirements. Those bidders who have followed the spirit as well as the letter of the specifications are likely to be concerned that they have been beaten on price by a provider who uses sub-

\footnotetext{
${ }^{155}$ C. Barnard, above n. 137.

${ }^{156}$ A. Koukiadaki, 'The Far-Reaching Implications of the Laval Quartet: the case of the UK living wage' (2014) 43 ILJ 91, 108.

${ }^{157}$ A. Koukiadaki, above n.156, especially pp. 106-114.

${ }^{158}$ See also OGC, Procurement Policy Note - Quarterly Update (London OGC, 2009), 4. See also http://www.telegraph.co.uk/news/politics/9656627/Downing-Street-says-Boris-Johnsons-living-wage-may-beillegal.html.

${ }^{159}$ European Parliament, 'Answer given by Mr McCreevy on behalf of the European Commission', 11 March 2009, http://www.europarl.europa.eu/sides/getAllAnswers.do?language=EN\&reference=P-2009-0922. For discussion in Scotland, see Local Government and Regeneration Committee, Living Wage Enquiry, Scottish Parliament, 21 December 2011, 485. See also http://readyforbusiness.org/2015/01/using-procurement-toachieve-the-living-wage/ (last accessed 2 July 2015).

${ }^{160}$ Above n. 156, 113.
} 
contractors to circumvent (more expensive) requirements and may mount a legal challenge. It is accordingly essential and, it is argued, entirely proportionate (especially given the high legal costs of defending a formal challenge and the automatic freeze on signing the contract ${ }^{161}$ ) to leave bidders free to choose how they will deliver the contract (themselves or through sub-contracts) but to require them to ensure that all (or at least all important) sub-contractors meet the requirements as well. ${ }^{162}$

Article 71 of Directive 2014/24 goes some way towards helping BCC deal with subcontractors. It introduces a new provision on subcontracting. ${ }^{163}$ It requires competent national authorities, such as labour inspectors or their equivalent, to take appropriate action to ensure that not only contractors but also subcontractors respect the labour law clause in Article 18(2). ${ }^{164}$ Article 71(6) provides that 'With the aim of avoiding breaches of the obligations referred to in Article 18(2) appropriate measures may be taken'. ${ }^{165}$ These include verifying whether there are grounds for exclusion of the subcontractors pursuant to Article 57 in which case the subcontractor must/may be replaced, or where the Member States provides for a mechanism of joint liability, they must ensure that the relevant rules are applied in compliance with Article 18(2).

The rest of Article 71 is about transparency: enabling the relevant authorities to know exactly who is on, for example, a building site or doing the highway maintenance. Thus, Article 71(2) provides that, in the procurement documents, the CA may ask the tenderer to indicate in its tender any share of the contract it intends to subcontract to third parties and any proposed subcontractors. Article 71(5) provides that in the case of works contracts and in respect of services to be provided at a facility under the direct oversight of the CA, the CA must require the main contractor to indicate the name, contact details and legal representatives of its subcontractors involved in such works or services, in so far as known.

\section{E. Conclusions}

For a local council, like BCC, the General Directive provides the green light for social creativity in procurement and a strong indication that the EU - and the European Commission in particular - far from being a threat will in fact now be supportive of targeted social initiatives. ${ }^{166}$ The Scottish government has long pushed at the frontiers of what can be delivered through social procurement. ${ }^{167}$ This is particularly visible in its Procurement (Reform) Scotland Act 2014. CAs, like BCC in other parts of the UK, have now been empowered by Directive 2014/24 to follow. There are some good precedents: Network Rail, for example, has a 'Code of Conduct for Labour' which

\footnotetext{
${ }^{161}$ See Regulation 95 of SI 2015/102

162 I am grateful to James Robinson for this point.

${ }^{163}$ See also the UK's Crown Commercial Services Guidance on the New Subcontracting Provisions, https://www.gov.uk/guidance/transposing-eu-procurement-directives.

${ }^{164}$ Art. 71(1). See also Rec. 105.

${ }^{165}$ The UK's implementation is less robust. There is no reference to Reg. 56(2). It provides only for the possibility for excluding subcontractors under Reg. 57: Regs 71(8) and (9).

${ }^{166}$ Although it is said that the Commission, when auditing use of EU grant funding, does take a harsh approach to the rules.

${ }^{167}$ See also its excellent 'procurement journey' website http://www.scotland.gov.uk/Topics/Government/Procurement/buyer-information/spdlowlevel.
} 
establishes 'some minimum standards that we expect in our supply chain'. ${ }^{168}$ It continues 'We must work to achieve our vision of everyone going home safe everyday. That will mean we often have to go beyond this baseline'. ${ }^{169}$ And they make the economic case too: 'Outstanding safety performance and business performance go hand in hand'. ${ }^{170}$

However, delivering on a social agenda requires a certain amount of courage and determination from Member States. As the UK government notes, 'Often we have been over-conservative and risk averse in approaches to procurement'. ${ }^{171}$ Directive 2014/24 sends out a strong signal that this needs to change and the UK government has recognised this. However, this view is not universally shared. There are still some who argue that strategic or smart use of public procurement can generate market distortions and so advocate a strict proportionality test to the promotion of horizontal procurement policies. ${ }^{172}$ Proportionality is a principle that many in government are afraid of, due to its very indeterminacy and the lack of certainty ex ante.

For these reasons, social procurement requires courage from CAs like BCC since it is they who risk being sued by unsuccessful bidders, not the states themselves. Further, as Doherty notes, the institution of an automatic stay on the procurement process has 'encouraged more litigation on procurement matters'. ${ }^{173}$ This view is supported by empirical research conducted by Arrowsmith and Craven. ${ }^{174}$ Their questionnaire data reveal a 'steady rise of incidents of suppliers seeking legal advice from solicitors firms' relating to violations of EU procurement law. The recession seems to have aggravated this trend somewhat. However, in the 'overwhelming majority' of cases no legal challenge results. Reasons for this include time limits for bring claims, the costs and time involved in bringing a claim, that the CA has already taken remedial corrective action (such as rewinding the procedure), fear of reprisals by the CA (although less than in the past), and uncertainty about the legal case. More reassuringly for BCC, Arrowsmith and Craven found that 'a limited role for the damages remedy in public procurement disputes', given the 'very limited number of successful damages claims in court actions'. ${ }^{175}$ For this reason, socially minded CAs should welcome Directive 2014/24. Yes, it creates some uncertainty but, more generally, it empowers CAs to boldly go.

\footnotetext{
${ }^{168}$ Network Rail Code of Conduct for Labour (version 1- February 2015), 3.

169 Ibid.

${ }^{170}$ Ibid, 4.

${ }^{171}$ Crown Commercial Service, 'Reform of the EU Procurement rules - public sector, briefing for Procurement Practitioners, 2014, 9.

172 A. Sanchez Graells, 'Truly Competitive Public Procurement as a Europe 2020 Lever: What Role for the Principle of Competition in Moderating Horizontal Policies?' (2015) 22 EPL 377.

${ }^{173}$ B. Doherty, above n.34, 796.

${ }^{174}$ S. Arrowsmith and R. Craven, 'Supplier litigation behaviour in the United Kingdom: A preliminary perspective based on perspectives of legal advisors', not yet published, on file with the author, sections 4.34.3.

${ }^{175}$ On the principles for damages, see Harmon CFEM Facades (UK Ltd) $v$ The Corporate Officer of the House of Commons (2000) 2 LGLR 372 where the parties were reported as settling for $£ 1.8$ million after the judgment: H. Beale, W. Bishop, M. Furmston, Contract: Cases and Materials (Oxford, OUP, 2007, $5^{\text {th }}$ ed), 248. See also Aquatron Marine v Strathclyde Fire Board [2007] CSOH 185 where damages were awarded of £122,149.20. Other settlement agreements must exist because few of the procurement challenges have proceeded all the way to full trial. Some of those settlements are subject to confidentiality clauses meaning that the quantum of damages cannot be disclosed.
} 